\title{
PENGARUH PENGGUNAAN MODEL PEMBELAJARAN BERBASIS PROYEK BERBANTUAN GOOGLE CLASSROOM TERHADAP HASIL BELAJAR MAHASISWA PENDIDIKAN BIOLOGI
}

\author{
Maria Waldetrudis Lidi ${ }^{1}$, Maimunah H. Daud ${ }^{2}$ \\ Program Studi Pendidikan Biologi, Universitas Flores \\ e-mail: waldetrudismaria1024@gmail.com
}

\begin{abstract}
ABSTRAK
Penelitian ini bertujuan untuk mengetahui pengaruh penggunaan model pembelajaran berbasis proyek berbantuan google classroom di masa pandemi terhadap hasil belajar mahasiswa program studi pendidikan biologi. Jenis penelitian ini adalah penelitian ex-post facto. Populasi dalam penelitian ini adalah mahasiswa program studi pendidikan biologi yang berjumlah 72 orang, dengan sampel penelitian berjumlah 34 orang yang diperoleh dengan menggunakan teknik purposive sampling. Data yang diperoleh melalui hasil wawancara dan dokumentasi, yang berupa data hasil belajar mahasiswa. Analisis data digunakan dengan uji-t. Hasil penelitian menunjukkan bahwa penerapan project based learning berbantuan google classroom di masa pandemic covid 19 berpengaruh terhadap hasil belajar siswa, yang diperoleh nilai $t_{\text {hitung }}=11,957$ dengan $\bar{x}=15,353$ nilai sig. (2-tailed) $0,000<0,05$ dengan $\alpha=0,05$.
\end{abstract}

Kata Kunci: Proyek, Google classroom, hasil belajar

\section{ABSTRACT}

This study aims to determine the effect of using a project-based learning model assisted by Google Classroom during the pandemic on the learning outcomes of students in the biology education study program. This type of research is ex-post facto research. The population in this study were students of the biology education study program, totaling 72 people, with a research sample of 34 people obtained using purposive sampling technique. Data obtained through interviews and documentation, in the form of student learning outcomes data. Data analysis was used by t-test. The results showed that the implementation of project based learning assisted by google classroom during the covid 19 pandemic affected student learning outcomes, which obtained the value of $\mathrm{t} \_$count $=11.957$ with $\mathrm{x}=15.353$ sig value. (2-tailed) $0.000<0.05$ with $=0.05$.

Key words: Project, Google classroom, learning outcomes. 


\section{PENDAHULUAN}

Selama masa pandemi Covid 19 sistem pendidikan di Indonesia telah mengalami perubahan dari sistem pendidikan formal yang berbasis tatap muka langsung menjadi sistem online. Perubahan pola pembelajaran yang mengedepankan teknologi ini sejalan dengan tuntutan masa depan yang menjadikan teknologi sebagai alat bantu pembelajaran di era digital. Nizam dalam Hendayana (2020: 2), mengungkapkan bahwa masa pandemi menjadi tantangan dalam mengembangkan kreativitas terhadap penggunaan teknologi untuk meningkatkan keterampilan self-directed learning di abad 21 ini.

Menurut Lestari (2018: 97), teknologi dapat dimanfaatkan sebagai penunjang keberhasilan pembelajaran sebagai media pembelajaran, alat administrasi, dan sumber belajar. Salah satu contoh peran teknologi sebagai media pembelajaran dalam mendukung dan meningkatkan pengetahuan dan keterampilan adalah internet. Salah satu contoh pembelajaran berbasis internet adalah penggunaan aplikasi google classroom.

Google classroom adalah aplikasi yang bertujuan untuk membantu dosen dan peserta didik untuk berinteraksi, mengorganisasikan kelas dan berkomunikasi tanpa harus terikat dengan jadwal kuliah di kelas. Dosen juga dapat langsung memberikan tugas dan memberikan nilai langsung kepada mahasiswa (Miarso, 2016: 571 ). Google classroom memungkinkan kegiatan pembelajaran menjadi lebih produktif dan bermakna dengan menyederhanakan tugas, meningkatkan kolaborasi, dan membina komunikasi, pengajar dapat membuat kelas, memberikan tugas, mengirim masukan, dan melihat semuanya di satu tempat (Atikah, dkk., 2021: 16). Di dukung oleh Su'uga, dkk., (2020: 608), yang menyatakan bahwa google classroom merupakan platform belajar secara online yang bisa digunakan pada smartphone atau PC dengan berbagai fitur yang berguna untuk memudahkan proses pembelajaran, lebih efektif, menghemat waktu dan tempat dan tidak pernah digunakan sebagai konten berbayar.

Adanya keterbatasan tatap muka secara langsung antara pendidik dan peserta didik menuntut tenaga pendidik untuk memilih model pembelajaran yang dapat memfasilitasi peserta didik untuk meningkatkan pengetahuan dan keterampilannya secara mandiri. Salah satu alternatif model pembelajaran yang dapat digunakan adalah model pembelajaran berbasis proyek. Model pembelajaran berbasis proyek adalah model pembelajaran yang bermuara pada proses pelatihan berdasarkan masalah nyata melalui kegiatan proyek dan dijalankan dengan cara-cara: kerja kelompok, investigasi secara mandiri, mengembangkan keterampilan individual dan sosial serta meningkatkan pemahaman (Murniarti,-: 372). Hal tersebut selaras dengan apa yang dikemukakan oleh Wulandari (2016: 252), yakni pembelajaran berbasis proyek adalah metode pembelajaran yang menggunakan proyek sebagai media untuk melakukan eksplorasi, penilaian, interpretasi, sintesis, dan informasi untuk menghasilkan berbagai bentuk hasil belajar.

Hasil penelitian terdahulu oleh Sholihah dan Pertiwi (2019: 72), menunjukkan bahwa penerapan project based learning dapat meningkatkan hasil belajar mahasiswa pada mata kuliah dasar-dasar sains. Hal ini senada dengan temuan Nusa (2021: 212 ), menjelaskan bahwa penerapan project based learning lebih efektif dibandingkan dengan model pembelajaran konvensional, selain itu sebagian besar mahasiswa menyatakan bahwa pembelajaran berbasis proyek memotivasi mahasiswa untuk berhasil melalui kegiatan yang menarik. Penerapan pembelajaran berbasis proyek tidak hanya meningkatkan hasil belajar 
mahasiswa tetapi juga dapat meningkatkan kreativitas mahasiswa dalam menghasilkan karya yang dapat membantu proses pembelajaran pada mata kuliah IPA SD (Rati., dkk., 2017: 68). Selain itu, penggunaan teknologi seperti media sosial telah menjadi budaya saat ini. Salah satunya terlihat dari temuan Esto, dkk (2019: 48) yakni sebesar 82.22\% peserta didik kelas IPA di SMAN 1 Talibura berkategori sering menggunakan media sosial. Sehingga dapat disimpulkan bahwa penggunaan teknologi sudah menjadi budaya baru masyarakat di zaman ini.

Berdasarkan uraian di atas maka diperlukan adanya analisis pengaruh penerapan model pembelajaran berbasis proyek dalam pembelajaran online bagi mahasiswa. Pembelajaran berbasis proyek melalui google classroom disinyalir efektif dalam meningkatkan hasil belajar. Hal ini dikarenakan melalui proyek mahasiswa diberi latihan menyelesaikan permasalahan nyata melalui kegiatan/proyek secara mandiri. Adapun yang menjadi tujuan penelitian ini adalah untuk mengetahui pengaruh penggunaan model pembelajaran berbasis proyek melalui google classroom terhadap hasil belajar mahasiswa.

\section{METODE}

Jenis penelitian yang digunakan adalah Ex-Post facto dengan pendekatan deskriptif kuantitatif. Desain penelitian Ex-Post facto disajikan pada Gambar 1.

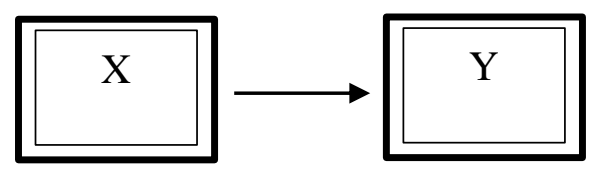

Gambar 1. Desain penelitian Ex-Post Facto

Penelitian telah dilaksanakan di Program Studi Pendidikan Biologi Universitas Flores pada bulan Mei-Juni 2021. Subjek penelitian dalam penelitian ini adalah mahasiswa Program studi Pendidikan Biologi Universitas Flores dengan jumlah populasi 72 mahasiswa. Teknik penarikan sampel menggunakan teknik purposive sample. Sampel yang dipilih adalah mahasiswa semester IV sebanyak 34 mahasiswa pada mata kuliah fisiologi hewan. Teknik pengumpulan data yang digunakan dalam penelitian adalah dokumentasi yaitu berupa nilai hasil belajar mahasiswa. Instrumen yang digunakan dalam penelitian ini adalah pedoman dokumentasi dan data wawancara sebagai pendukungnya. Data yang diperoleh akan dianalisis secara kuantitatif yakni dengan menggunakan analisis deskriptif dan analisis inferensial bantuan software statistical package for the social science (SPSS) versi 25. Penjabaran terkait kedua teknik analisis data disajikan sebagai berikut.

a. Analisis Deskriptif

Analisis statistik deskriptif dengan bantuan SPSS yaitu untuk melihat nilai minimum, maksimum, mean, dan standar deviasi hasil belajar.

b. Analisis inferensial

1. Uji prasyarat analisis

Uji prasyarat analisis yang digunakan yaitu uji normalitas untuk mengetahui apakah data hasil penelitian berasal dari populasi yang berdistribusi normal atau tidak. Pengujian normalitas dilakukan dengan menggunakan bantuan softwarestatistical 
package for the social sciences (SPSS) versi 25 yaitu menggunakan Kolmogorov Smirnov, dengan kriteria sebagai berikut:

a) Jika nilai signifikansi (Sig.) $>0,05$ maka data penelitian berdistribusi normal.

b) Sebaliknya, jika nilai signifikansi (Sig.) $<0,05$ maka data penelitian tidak berdistribusi normal.

2. Uji Hipotesis

Dalam penelitian ini menggunakan one sample test dan dibandingkan dengan nilai KKM 65. Pengujian ini dilakukan dengan bantuan software statistical package for the social sciences (SPSS) versi 25. Dasar pengambilan keputusan adalah jika signifikan (sig. 2 - tailed) 0,000<0,05 maka $H_{o}$ ditolak dan $H_{1}$ diterima. Kaidah keputusannya jika $a=0,05 \geq$ nilai signifikan (2-tailed) maka $H_{o}$ ditolak dan $H_{1}$ diterima.Jika $a=0,05 \leq$ nilai signifikan (2-tailed) maka $H_{o}$ diterima dan $H_{1}$ ditolak (Machali, 2015: 57).

$H_{o}=$ Ada pengaruh penggunaan model pembelajaran berbasis proyek berbantuan google classroom terhadap hasil belajar mahasiswa program studi pendidikan biologi Universitas Flores.

$H_{1}=$ Tidak ada pengaruh penggunaan model pembelajaran berbasis proyek berbantuan google classroom terhadap hasil belajar mahasiswa program studi pendidikan biologi Universitas Flores

\section{HASIL DAN PEMBAHASAN}

Data penelitian yang telah diperoleh selanjutnya dianalisis secara deskriptif dan inferensial sebelum dilakukan uji hipotesis.

1. Analisis deskriptif

Data hasil analisis deskriptif disajikan pada Tabel 1.

Tabel 1. Hasil Belajar

\begin{tabular}{|c|c|c|c|c|c|}
\hline \multicolumn{6}{|c|}{ Descriptive Statistick } \\
\hline \multirow{3}{*}{ Hasil Belajar } & $\mathrm{N}$ & Minimum & Maximum & Mean & $\begin{array}{c}\text { Std. } \\
\text { Deviation }\end{array}$ \\
\cline { 2 - 6 } & 34 & 65 & 95 & 80,4 & 7,5 \\
\hline
\end{tabular}

Hasil belajar siswa selanjutnya digolongkan ke dalam beberapa kriteria rentangan nilai yang disajikan pada Gambar 2 berikut. Hal ini bertujuan untuk melihat besarnya persentase pada setiap kriteria. 


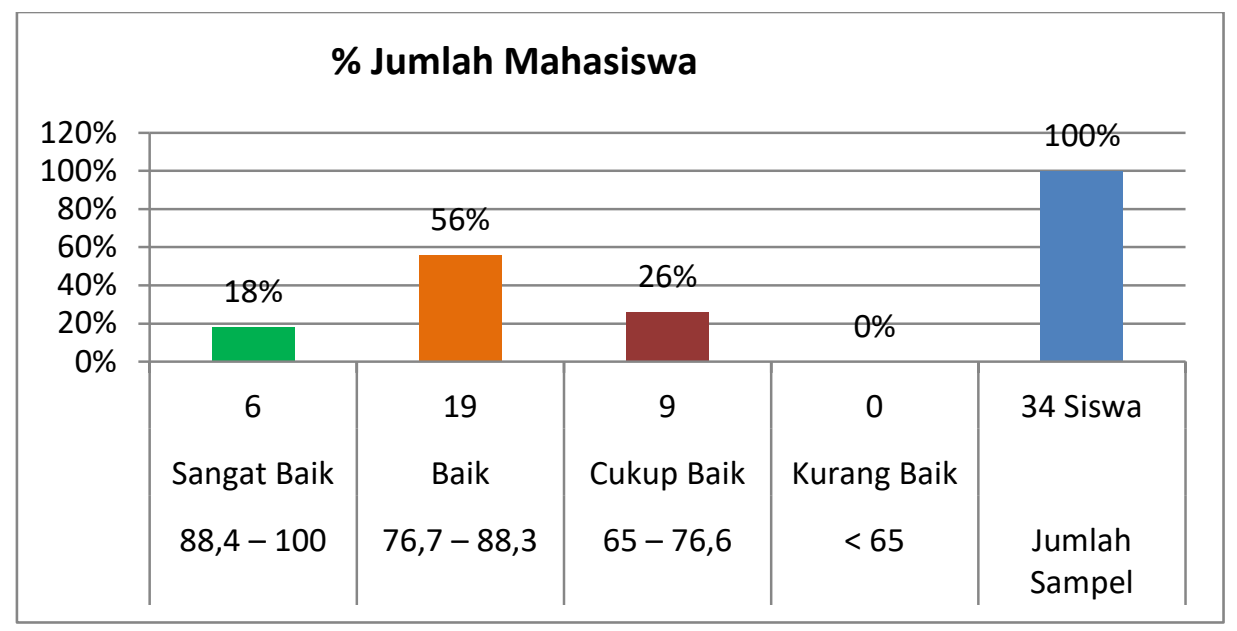

Gambar 2. Diagram Rentangan Nilai

Data pada Tabel 1 dan Gambar 2 menunjukkan bahwa hasil belajar mahasiswa berada di atas KKM yang telah ditentukan. Sebesar 56\% nilai mahasiswa berada pada kriteria baik, $26 \%$ mahasiswa berada pada kriteria cukup baik, $18 \%$ mahasiswa berada pada kriteria sangat baik dan kriteria kurang baik sebesar 0\%. Hal ini menunjukkan bahwa hasil belajar mahasiswa berkategori tuntas.

2. Analisis Inferensial

a) Uji Normalitas Hasil Belajar

Uji normalitas dalam penelitian ini menggunakan software SPSS. Hasil uji normalitas hasil belajar siswa dapat dilihat pada Tabel 2 .

Tabel 2. Uji Normalitas Hasil Belajar

\begin{tabular}{|l|r|r|l|r|r|c|}
\hline \multicolumn{9}{|c|}{ Tests of Normality } \\
\hline & \multicolumn{2}{|c|}{ Kolmogorov-Smirnov ${ }^{\mathrm{a}}$} & \multicolumn{3}{|c|}{ Shapiro-Wilk } \\
\cline { 2 - 8 } & Statistic & \multicolumn{1}{|c|}{ Df } & \multicolumn{1}{c|}{ Sig. } & Statistic & Df & \multicolumn{1}{c|}{ Sig. } \\
\hline Hasil belajar & 0.109 & 34 & $0.200^{*}$ & .978 & 34 & 0.705 \\
\hline
\end{tabular}

Berdasarkan data pada Tabel 2 uji normalitas di atas dapat diketahui bahwa data hasil penelitian berasal dari populasi yang berdistribusi normal. Di mana jika nilai probalitas $\geq$ tingkat signifikan maka $H_{0}$ diterima dan $H_{1}$ ditolak. Jadi kesimpulannya bahwa data berdistribusi normal dengan nilai $P=0,2 \geq 0,05$.

b) Uji Hipotesis

Hasil uji hipotesis disajikan pada Tabel 3 dan Tabel 4 berikut.

Tabel 3. Uji Hipotesis Hasil Belajar

\begin{tabular}{|l|r|c|c|c|}
\hline \multicolumn{5}{|c|}{ One-Sample Statistics } \\
\hline & $\mathrm{N}$ & Mean & $\begin{array}{c}\text { Std. } \\
\text { Deviation }\end{array}$ & $\begin{array}{c}\text { Std. Error } \\
\text { Mean }\end{array}$ \\
\hline Hasil belajar & 34 & 80.35 & 7.487 & 1.284 \\
\hline
\end{tabular}


Berdasarkan hasil perhitungan pada tabel di atas dari 34 jumlah siswa, nilai mean sebesar 80,35 , standar deviasi sebesar 7,487 dan standar error mean yaitu 1,284. Untuk data secara lengkap mengenai perhitungan uji hipotesis hasil belajar menggunakan one-sampel statistics.

Tabel 4. Uji Hipotesis Menggunakan One-Sample Test

\begin{tabular}{|c|c|c|c|c|c|c|}
\hline \multicolumn{7}{|c|}{ One-Sample Test } \\
\hline & \multicolumn{6}{|c|}{ Test Value $=65$} \\
\hline & \multirow[b]{2}{*}{$\mathrm{T}$} & \multirow[b]{2}{*}{ Df } & \multirow{2}{*}{$\begin{array}{l}\text { Sig. }(2- \\
\text { tailed })\end{array}$} & \multirow{2}{*}{$\begin{array}{c}\text { Mean } \\
\text { Difference }\end{array}$} & \multicolumn{2}{|c|}{$\begin{array}{c}95 \% \text { Confidence Interval } \\
\text { of the Difference }\end{array}$} \\
\hline & & & & & Lower & Upper \\
\hline $\begin{array}{l}\text { Hasil } \\
\text { belajar }\end{array}$ & 11.957 & 33 & 0.000 & 15.353 & 12.74 & 17.97 \\
\hline
\end{tabular}

Berdasarkan Tabel 4 di atas diperoleh nilai $t=11,957$. Nilai rata - rata yang diperoleh $X=15.353$. Dari tabel di atas menunjukkan nilai sig. (2-tailed) 0,000<0,05. Jadi $H_{0}$ ditolak dan $H_{1}$ diterima sehingga dapat disimpulkan bahwa ada pengaruh penerapan project based learning terhadap hasil belajar mahasiswa program studi pendidikan biologi.

Hasil pengujian hipotesis menunjukkan bahwa pembelajaran berbasis proyek berbantuan google classroom di masa pandemi Covid 19 berpengaruh terhadap hasil belajar mahasiswa. Hal ini juga didukung oleh hasil wawancara kepada responden yang menyatakan bahwa pembelajaran berbasis proyek membantu mahasiswa untuk menggali pengetahuan bersama rekan kelompoknya, membangkitkan motivasi dan kepercayaan diri dan meningkatkan kreativitas dan keterampilan mahasiswa. Selain itu pemanfaatan google classroom di masa pandemi Covid 19 membangkitkan antusiasme mahasiswa dalam belajar, dan memudahkan dalam pengerjaan dan pengumpulan tugas karena mudah digunakan dalam pengoperasiannya. Hal ini senada dengan yang dikemukakan oleh Yance, dkk (2013: 52) yakni project based learning merupakan model pembelajaran yang dapat mengaktifkan peserta didik dalam belajar melalui kegiatan konstruksi pengetahuan, pengembangan kemampuan sosial melalui diskusi dan kerjasama kelompok dan meningkatkan kreativitas siswa dalam menghasilkan produk dari proyek yang dikerjakan. Didukung oleh temuan sebelumnya oleh Fauziah, dkk (2017: 46), project based learning melalui google classroom meningkatkan partisipasi, kreatif, semangat, motivasi dan inovasi mahasiswa, ditambah lagi dengan adanya kemudahan siswa dalam diskusi bersama rekan kelompoknya dan dosen melalui google classroom yang dapat digunakan melalui handphone. Selain itu, pembelajaran online dengan memanfaatkan platform google classroom secara tidak langsung melatih dan mempersiapkan peserta didik melalui penguasaan teknologi informasi dan komunikasi dalam menghadapi kompetisi di abad 21 (Danurahman, dkk., 2021: 72). Dengan demikian berdasarkan uraian di atas dapat disimpulkan bahwa pembelajaran berbasis proyek berbantuan google classroom berpengaruh dalam meningkatkan hasil belajar. Hal ini disebabkan kegiatan/proyek ilmiah melibatkan seluruh 
kemampuan mahasiswa seperti kemampuan berpikir kritis, kreatif dan inovatif, keterampilan sosial, kemandirian, komunikasi, dan kemampuan menggunakan teknologi.

\section{PENUTUP}

Adapun kesimpulan dari penelitian ini adalah project based learning berbantuan google classroom di masa pandemi Covid 19 berpengaruh terhadap hasil belajar mahasiswa program studi pendidikan biologi yang terlihat dari hasil belajar yang berada di atas kriteria ketuntasan dan berkategori sangat baik dan baik. Hal ini dilihat dari sig. (2-tailed) $>$ 0,05, yaitu $0,000<0,05$.

\section{UCAPAN TERIMA KASIH}

Penulis menghaturkan limpah terima kasih yang berlimpah kepada Ketua Program studi Pendidikan biologi Universitas Flores atas dukungannya penelitian ini dapat selesai tepat waktu dan memperoleh hasil yang memuaskan. Penulis juga mengucapkan terima kasih kepada pihak pengelola jurnal Optika: jurnal Pendidikan fisika atas kesediaannya menerima, merevisi, dan mempublikasikan artikel ilmiah ini.

\section{DAFTAR PUSTAKA}

Atikah, R., Prihatin, R. T., Hernayati, H., dan Misbah, J. (2021). Pemanfaatan Google Classroom sebagai Media Pembelajaran di Masa Pandemi Covid-19. Jurnal Pendidikan Teknologi Informasi dan Komunikasi, 7 (1), 7-18.

Danurahman, J., Hermawan, H dan Mazid, S. (2021). Keefektifan Penggunaan Media Google Classroom Dalam Proses Pembelajaran di Masa Pandemi. Jurnal Kalacakra, 2, (2), 65-74.

Esto, E., Daud, M. H dan Ilyas. (2019). Pengaruh Penggunaan Media Sosial Terhadap Prestasi Belajar Peserta Didik Jurusan IPA SMAN 1 Talibura. Optika: Jurnal Pendidikan Fisika, 3 (2), 42- 52.

Fauziah, C., Taufiqulloh, Sudibyo, H. (2020). Implementasi Model Project Based Learning Pada Pembelajaran Jarak Jauh Berbasis E-Learning Selama Pandemi Covid-19. Pancasakti Science Education Journal, 5 (2), 38-48.

Hendayana, Y. 2020. Tantangaan Dunia Pendiidkan di masa Pandemi. Di akses di https://dikti.kemdikbud.go.id/kabar-dikti/kabar/tantangan-dunia-pendidikan-di-masapandemi/umasDitjenDiktiKementerian Pendidikan dan Kebudayaan pada tanggal 13 Oktober 2021.

Lestari, S. (2018). Peran Teknologi Dalam Pendidikan di Era Globalisasi. Jurnal Edureligia, 2 (2), 94-100.

Machali I. (2015). Statistik Itu Mudah Menggunakan SPSS Sebagai Alat Bantu Statistik. Yogyakarta: Lembaga Ladang Kata.

Miarso, Y. (2016). Menyemai Benih Teknologi Pendidikan. Jakarta: Kencana

Murniarti, E.-. Penerapan Metode Project Based Learning Dalam Pembelajaran. Diakses di http://ap.fip.um.ac.id/wp-content/uploads/2016/03/28-Erni-Murniarti.pdf pada tanggal 13 Oktober 2021.

Nusa, J. G. N. (2021). Efektivitas Model Project Based Learning Pada Mata Kuliah Vulkanologi Terhadap Hasil Belajar Mahasiswa. Jurnal Ilmiah Mandala Education, 7 (2), 210-214.

Rati, N. W., Kusmaryatni, N dan Rediani, N. (2017). Model Pembelajaran Berbasis Proyek, Kreativitas dan Hasil Belajar Mahasiswa. Jurnal Pendidikan Indonesia, 6 (1), 60-71. 
Su'uga, H.S., Ismayati, E., Agung, A.I dan Rijanto, T. (2020). Media E-Learning Berbasis Google Classroom Untuk Meningkatkan Hasil Belajar Siswa SMK. Jurnal Pendidikan Teknik Elektro, 9 (3), 605-610.

Wulandari, F. E. (2016). Pengaruh Pembelajaran Berbasis Proyek Untuk Melatihkan Keterampilan Proses Mahasiswa. Jurnal Pedagogia, 5 (2), 247-254.

Sholihah, F. N dan Pertiwi, N. A. (2019). Penerapan Project Based Learning Untuk Meningkatkan Hasil Belajar Mahasiswa Pada Matakuliah Dasar-dasar Sains. Jurnal Edubiotik, 4 (2), 68-74.

Yance, R. D., Ramli, E dan Mufit, F. (2013). Pengaruh Penerapan Model Project Based Learning Terhadap Hasil Belajar Fisika Kelas XI IPA SMA Negeri 1 Batipuh Kabupaten Tanah datar. Pillar of Physics Education, 1, 48-54. 